\title{
Evaluation of Sequential Application of Insecticides against Pod Borer of Pigeonpea [Cajanus cajan (L.) Millsp.]
}

\author{
S.D. Bantewad*, D.K. Patil and J.E. Jahagirdar \\ Agricultural Research Station Badnapur, Dist. Jalna, Vasantrao Naik Marathwada Krishi \\ Vidyapeeth, Parbhani (MS.), India \\ *Corresponding author
}

\section{A B S T R A C T}

\section{Keywords \\ Pigeonpea, Pod borer, Pod damage, Grain damage, Insecticides \\ Article Info \\ Accepted: \\ 18 August 2018 Available Online: 10 September 2018}

The present study was conducted to evaluate the sequential application of different insecticidal treatments against pod borer [Helicoverpa armigera (Hubner)], tur pod fly [Melanagromyza obtusa (Malloch)] infesting pigeonpea variety BSMR 736 during Kharif 2015-16 and 2017-18. Among all the treatment with application of first spray chlorantraniliprole $18.5 \mathrm{SC} @ 0.3 \mathrm{ml} / \mathrm{l}$ of water at $50 \%$ flowering stage and second spray of flubendiamide $39.35 \mathrm{SC} @ 0.2 \mathrm{ml} / 1$ of water at pod development stage provided better control of Helicoverpa armigera and Melanagromyza obtusa on pigeonpea in terms of lower pod and grain damage and getting higher grain yield. Hence, these two sequential applications of insecticides can be suggested to the farmers for effective management of pod borers on pigeonpea.

\section{Introduction}

Pigeonpea [Cajanus cajan] is an important pulse crop grown in semi-arid tropics and subtropical areas of the world (Van der Maesen, 1991). India accounts for more than 90 per cent of the world's pigeonpea production and area (Mathukia et al., 2016). In India pigeonpea is grown in area of 5.21 million hectares with an annual production of about 4.23 million tonnes and the average productivity is $826 \mathrm{~kg} / \mathrm{ha}$., whereas, in Maharashtra, pigeonpea is cultivated an area of 15.33 lakh hectares with an annual production of 11.70 lakh tonnes and the average productivity is $764 \mathrm{~kg} / \mathrm{ha}$ (Anonymous, 2017). It is a rich source of protein $(21.71 \%)$ and supplies a major share of protein requirement of the vegetarian population of the country [Singh et al., 2015]. In spite of all the improvements brought about in the cultivation of pigeonpea crops, the major constraints for low productivity of pigeonpea are inadequate availability of seeds of improved varieties, biotic and abiotic stresses and poor crop management (Ali, 2012). Abiotic and biotic stresses are the most limiting factors in pigeonpea production. Among the biotic pressures, large numbers of insect pests have been identified to infest pigeonpea. The low yields of pigeonpea crop which have remained stagnant for the past 3 to 4 decades are mainly due to insect pest attack and physiological shriveling. 
Amongst many insect pests attacking pigeonpea crop as gram pod borer, Helicoverpa armigera (Hubner), legume pod borer, Maruca vitrata (Geyer) and pod fly, Melanagromyza obtusa (Malloch) causes significant reduction in the crop yield of pigeonpea (Sujithra and Chander, 2014). As per a conservative estimate, losses due to these insect pests may vary from 27 per cent to even 100 per cent in pigeonpea (Srilaxmi and Paul, 2010).

Pod borers have been estimated to cause 60 to 90 per cent loss in the grain yield of pigeonpea under favorable conditions and the damage of seeds by pod fl generally ranges between 14.3 to 46.6 per cent (Priyadarshini et al., 2013). $H$. armigera and $M$. obtusa cause adequate economic damage leading to very low yield levels of 500 to $800 \mathrm{~kg}$ ha-1 as against the potential yield of 1800 to $2000 \mathrm{~kg}$ ha-1 (Durairaj and Shanower, 2003; Lal, 1996).

For management of pod borer complex, agrochemicals are still the first choice of farmers. Insecticides are most commonly recommended, preferred and adopted means, especially for crop with high remunerative prices like pigeonpea. Hence, chemical measures are often termed as necessary evil in present pigeonpea pest management scenario (Wadaskar et al., 2013). Farmers, use chemical pesticides indiscriminately, which leads to increased cost of plant protection resulting in lower profitability.

On these grounds, newer insecticides with novel mode of action are needed to be evaluated to find out an effective and economical insecticide for the management of pigeonpea pod borer complex (Patange and Chiranjeevi, 2017). Keeping these views in mind, present study was conducted to evaluate the efficacy of sequential application of certain insecticides against pod borers and pod bug in pigeonpea ecosystem.

\section{Materials and Methods}

Field experiments on pigeonpea (var. BSMR 736) were conducted at Agriculture Research Station, Badnapur, Vasantrao Naik Marathwada Krishi Vidyapeeth, Parbhani during Kharif seasons of 2015-16 and 201718. The crop was grown at a spacing of $90 \mathrm{~cm}$ $X 20 \mathrm{~cm}$ with three replications and eight treatments including control in randomized block design. Two applications of respective insecticides, first at $50 \%$ flowering and remaining at pod development stage (21 days after first spray) were made using knapsack sprayer with hollow cone nozzle. The sprays were applied at evening hours to minimize the toxicity for relative pollinators and support their conservation. The pretreatment count was made a day before while, post treatment count were made on three and seven days after each spray, respectively. All the recommended practices were adopted for raising the crop.

The damage caused by the larvae of pod borer (H. armigera), identified by the nature of damage caused by them to the pods by way of holes on the pods. The larvae of $H$. armigera cut a bigger and irregular hole on the pods and feed on the developing grains. The observation recorded on the number of $H$. armigera larvae per plant. Five plants were randomly selected from each net plot and three twigs per plant i.e. one each from top, middle and bottom were selected at the time of each observation the total number of $H$. armigera were recorded. The observations on number maggots and pupae of pod fly were recorded from 50 green pods from randomly selected five plants. Sample pods were critically examined for the damage of major insect pests' viz. H. armigera and M. obtusa, as described by Yadav and Dahiya (2004). The total yield per plot including the yield of pods sampled earlier for assessment of pod damage was then computed on kilogram per hectare basis. 


\section{Statistical analysis}

The data recorded during the course of investigation were subjected to statistical analysis by using analysis of variance (ANOVA) technique for Randomized Block Design to compare means of different treatments as suggested by Panse and Sukhatme (1985).

\section{Results and Discussion}

The results obtained from the present investigation as well as relevant discussion have been summarized under the following heads:

\section{Effects of various treatments on population of $\boldsymbol{H}$. armigera}

The results revealed that on the basis of pooled data indicated that the populations of $H$. armigera were non-significant at one day before spray and after 3 and 7 days after spray (Table 1), all the insecticides treatments were found significantly superior over control in reducing the larval population of $H$. armigera.

After first application of insecticide treatments, 3 days after spray and 7 days after spray $\mathrm{T}_{3}, \mathrm{~T}_{4}, \mathrm{~T}_{5}$ and $\mathrm{T}_{6}$ were spray of chlorantraniliprole 18.5 SC @ $0.3 \mathrm{ml} / 1$ was found effective in management of these pests at 50 per cent flowering or pod initiation stage of the crop at 3 DAS (0.36, 0.40, 0.41 and 0.42 larvae/plant) and 7 DAS $(0.21,0.21,0.21$ and 0.21 larvae/plant).

After second application of insecticide treatments, 3 days after spray and 7 days after spray $\quad \mathrm{T}_{6} \quad$ chlorantraniliprole $\quad 18.5 \quad \mathrm{SC} \quad$ @ $0.3 \mathrm{ml} / 1$ followed by flubendiamide $39.35 \mathrm{SC}$ @ $0.2 \mathrm{ml} / 1$ were spray at pod development stage of the crop was recorded at 3 DAS (0.31 larvae/plant) and 7 DAS (0.13 larvae/plant) which was at par with treatment $T_{5}, T_{4}$ and $T_{3}$ at 3 das $(0.45,0.68$ and 0.75 larvae/ plant $)$ and at 7 DAS $(0.18,0.35$ and 0.43 larvae/ plant), respectively.

\section{Effect of various treatments on population of M. obtuse on green pods}

The results revealed that on the basis of pooled data indicated that the populations of pod fly were non-significant at one day before spray and after 3 and 7 days after second spray (Table 1).

All the insecticides treatments were found significantly superior over control in reducing the maggot and pupal population of pod fly in green pods of pigeonpea. There was no population of pod fly at the time of first application (50 per cent flowering) of insecticide treatment.

After second application of insecticide treatments, 3 days after spray and 7 days after spray $\quad \mathrm{T}_{6} \quad$ Chlorantraniliprole $18.5 \quad \mathrm{SC} \quad$ @ $0.3 \mathrm{ml} / 1$ followed by flubendiamide $39.35 \mathrm{SC}$ @ $0.2 \mathrm{ml} / 1$ were spray at pod development stage of the crop was recorded lowest population at 3 DAS (0.22 maggots and pupa/ 50 green pods) and 7 DAS (0.10 maggots and pupa/ 50 green pods) which was at par with treatment $\mathrm{T}_{5}, \mathrm{~T}_{4}$ and $\mathrm{T}_{3}$ at $3 \mathrm{DAS}(0.24,0.47$ and 0.51 maggots and pupa/ 50 green pods) and at 7 DAS (0.12, 0.23 and 0.23 maggots and pupa/ 50 green pods), respectively.

The present findings are confirmed with Patange and Chiranjeevi (2017) also found rynaxypyr 18.5 SP @ 30g a.i./ha as most effective insecticide in minimizing the larval population of gram pod borer, plume moth and pod fly on pigeonpea. Similarly, Maurya et al., (2016) also reported chlorantraniliprole 10 SE @ $60 \mathrm{~g}$ a.i./ha to be highly efficacious against $H$. armigera on pigeonpea that resulted in cent per cent reduction of larval population over control 
Table.1 Effect of sequential application of insecticides against population of H. armigera and M. obtuse on pigeonpea

\begin{tabular}{|c|c|c|c|c|c|c|c|c|c|c|}
\hline \multirow[t]{4}{*}{$\begin{array}{l}\text { Tr. } \\
\text { No. }\end{array}$} & \multirow[t]{4}{*}{ Treatment details } & \multirow[t]{4}{*}{ Dose } & \multirow{2}{*}{\multicolumn{5}{|c|}{ No. of H.armigera larvae / plant }} & \multirow{2}{*}{\multicolumn{3}{|c|}{$\begin{array}{l}\text { No. of maggots and pupae of } \\
\text { pod fly/ } 50 \text { green pods } \\
\text { Pooled (2015-17) }\end{array}$}} \\
\hline & & & & & & & & & & \\
\hline & & & \multirow[t]{2}{*}{ BS } & \multicolumn{2}{|c|}{ First spray } & \multicolumn{2}{|c|}{ Second spray } & \multirow[t]{2}{*}{ BS } & \multicolumn{2}{|c|}{ Second spray } \\
\hline & & & & 3 DAS & 7 DAS & 3 DAS & 7 DAS & & 3 DAS & 7 DAS \\
\hline 1. & $\begin{array}{l}\text { Acephate } 75 \text { SP fby } \\
\text { Acephate } 75 \text { SP }\end{array}$ & $\begin{array}{l}1 \mathrm{~g} / 1 \\
1 \mathrm{~g} / \mathrm{l}\end{array}$ & $\begin{array}{c}2.02 \\
(1.59)\end{array}$ & $\begin{array}{c}1.07 \\
(1.25)\end{array}$ & $\begin{array}{c}0.77 \\
(1.13)\end{array}$ & $\begin{array}{c}1.11 \\
(1.27)\end{array}$ & $\begin{array}{c}0.66 \\
(1.08)\end{array}$ & $\begin{array}{c}2.07 \\
(1.60)\end{array}$ & $\begin{array}{c}0.70 \\
(1.10)\end{array}$ & $\begin{array}{c}0.30 \\
(0.90)\end{array}$ \\
\hline 2. & $\begin{array}{l}\text { Acetamiprid } 20 \text { SP fby } \\
\text { Acetamiprid } 20 \text { SP }\end{array}$ & $\begin{array}{l}0.2 \mathrm{~g} / 1 \\
0.2 \mathrm{~g} / 1\end{array}$ & $\begin{array}{l}1.95 \\
(1.56)\end{array}$ & $\begin{array}{c}0.98 \\
(1.22)\end{array}$ & $\begin{array}{c}0.70 \\
(1.10)\end{array}$ & $\begin{array}{c}1.02 \\
(1.23)\end{array}$ & $\begin{array}{c}0.60 \\
(1.05)\end{array}$ & $\begin{array}{c}1.89 \\
(1.54)\end{array}$ & $\begin{array}{c}0.66 \\
(1.05)\end{array}$ & $\begin{array}{c}0.29 \\
(0.89)\end{array}$ \\
\hline 3. & $\begin{array}{l}\text { Chlorantraniliprole } 18.5 \text { SC fby } \\
\text { Acephate } 75 \text { SP }\end{array}$ & $\begin{array}{c}0.3 \mathrm{ml} / 1 \\
1 \mathrm{~g} / 1\end{array}$ & $\begin{array}{l}1.85 \\
(1.53)\end{array}$ & $\begin{array}{c}0.42 \\
(0.96)\end{array}$ & $\begin{array}{c}0.21 \\
(0.84)\end{array}$ & $\begin{array}{c}0.75 \\
(1.12)\end{array}$ & $\begin{array}{c}0.43 \\
(0.96)\end{array}$ & $\begin{array}{c}1.93 \\
(1.56)\end{array}$ & $\begin{array}{c}0.51 \\
(1.00)\end{array}$ & $\begin{array}{c}0.23 \\
(0.85)\end{array}$ \\
\hline 4. & $\begin{array}{l}\text { Chlorantraniliprole } 18.5 \mathrm{SC} \text { fby } \\
\text { Acetamiprid } 20 \mathrm{SP}\end{array}$ & $\begin{array}{l}0.3 \mathrm{~g} / 1 \\
0.2 \mathrm{~g} / 1\end{array}$ & $\begin{array}{c}1.93 \\
(1.55)\end{array}$ & $\begin{array}{c}0.40 \\
(0.95)\end{array}$ & $\begin{array}{c}0.21 \\
(0.84)\end{array}$ & $\begin{array}{c}0.68 \\
(1.09)\end{array}$ & $\begin{array}{c}0.35 \\
(0.92)\end{array}$ & $\begin{array}{c}2.07 \\
(1.60)\end{array}$ & $\begin{array}{c}0.47 \\
(0.98)\end{array}$ & $\begin{array}{c}0.23 \\
(0.85)\end{array}$ \\
\hline 5. & $\begin{array}{l}\text { Chlorantraniliprole } 18.5 \mathrm{SC} \text { fby } \\
\text { Indoxacarb } 15.8 \mathrm{EC}\end{array}$ & $\begin{array}{l}0.3 \mathrm{ml} / 1 \\
0.7 \mathrm{ml} / 1\end{array}$ & $\begin{array}{l}1.65 \\
(1.46)\end{array}$ & $\begin{array}{c}0.36 \\
(0.93)\end{array}$ & $\begin{array}{c}0.21 \\
(0.84)\end{array}$ & $\begin{array}{c}0.45 \\
(0.97)\end{array}$ & $\begin{array}{c}0.18 \\
(0.82)\end{array}$ & $\begin{array}{c}1.99 \\
(1.58)\end{array}$ & $\begin{array}{c}0.24 \\
(0.86)\end{array}$ & $\begin{array}{c}0.12 \\
(0.79)\end{array}$ \\
\hline 6. & $\begin{array}{l}\text { Chlorantraniliprole } 18.5 \text { SC fby } \\
\text { Flubendiamide } 39.35 \mathrm{SC}\end{array}$ & $\begin{array}{l}0.3 \mathrm{ml} / 1 \\
0.2 \mathrm{ml} / 1\end{array}$ & $\begin{array}{c}2.00 \\
(1.58)\end{array}$ & $\begin{array}{c}0.41 \\
(0.95)\end{array}$ & $\begin{array}{c}0.21 \\
(0.84)\end{array}$ & $\begin{array}{c}0.31 \\
(0.90)\end{array}$ & $\begin{array}{c}0.13 \\
(0.79)\end{array}$ & $\begin{array}{c}1.96 \\
(1.57)\end{array}$ & $\begin{array}{c}0.22 \\
(0.85)\end{array}$ & $\begin{array}{c}0.10 \\
(0.77)\end{array}$ \\
\hline 7. & $\begin{array}{l}\text { Dimethoate } 30 \mathrm{EC} \text { fby } \\
\text { Dimethoate } 30 \mathrm{EC}\end{array}$ & $\begin{array}{l}1.3 \mathrm{ml} / 1 \\
1.3 \mathrm{ml} / 1\end{array}$ & $\begin{array}{c}2.06 \\
(1.60)\end{array}$ & $\begin{array}{c}1.00 \\
(1.22)\end{array}$ & $\begin{array}{c}0.88 \\
(1.17)\end{array}$ & $\begin{array}{c}1.28 \\
(1.34)\end{array}$ & $\begin{array}{c}0.71 \\
(1.10)\end{array}$ & $\begin{array}{c}2.00 \\
(1.58)\end{array}$ & $\begin{array}{c}0.70 \\
(1.10)\end{array}$ & $\begin{array}{c}0.33 \\
(0.91)\end{array}$ \\
\hline 8. & Untreated control (Water spray) & -- & $\begin{array}{c}2.17 \\
(1.63)\end{array}$ & $\begin{array}{c}1.98 \\
(1.57)\end{array}$ & $\begin{array}{c}2.22 \\
(1.65)\end{array}$ & $\begin{array}{c}3.02 \\
(1.88)\end{array}$ & $\begin{array}{c}2.98 \\
(1.86)\end{array}$ & $\begin{array}{c}2.25 \\
(1.66)\end{array}$ & $\begin{array}{c}1.76 \\
(1.50)\end{array}$ & $\begin{array}{c}2.15 \\
(1.63)\end{array}$ \\
\hline & $\mathrm{SE}+\underline{+(\mathrm{m})}$ & & 0.07 & 0.07 & 0.08 & 0.08 & 0.07 & 0.08 & 0.07 & 0.06 \\
\hline & $\mathrm{CD}$ at $5 \%$ & & NS & 0.21 & 0.23 & 0.22 & 0.20 & NS & 0.21 & 0.18 \\
\hline & $\mathrm{CV} \%$ & & 9.80 & 10.88 & 12.38 & 10.53 & 11.67 & 9.20 & 11.52 & 10.60 \\
\hline
\end{tabular}

Figures of population in parenthesis are $\sqrt{ } \mathrm{x}+0.5$ transformed value. BS- before spray DAS- days after spray 
Table.2 Effects of various treatments on per cent pod and grain damage due to H. armigera and M. obtuse

\begin{tabular}{|c|c|c|c|c|c|c|c|c|c|}
\hline \multirow{3}{*}{$\begin{array}{l}\text { Tr. } \\
\text { No. }\end{array}$} & \multirow[t]{3}{*}{ Treatment details } & \multirow[t]{3}{*}{ Dose } & \multicolumn{3}{|c|}{ Per cent pod damage } & \multicolumn{3}{|c|}{ Per cent grain damage } & \multirow{3}{*}{$\begin{array}{l}\text { Grain } \\
\text { yield } \\
\text { (Kg/ha) }\end{array}$} \\
\hline & & & \multicolumn{3}{|c|}{ Pooled(2015-17) } & \multicolumn{3}{|c|}{ Pooled (2015-17) } & \\
\hline & & & $\begin{array}{l}\text { Pod } \\
\text { borer }\end{array}$ & Pod fly & Total & Pod borer & Pod fly & Total & \\
\hline 1. & $\begin{array}{l}\text { Acephate } 75 \text { SP fby } \\
\text { Acephate } 75 \text { SP }\end{array}$ & $\begin{array}{l}1 \mathrm{~g} / 1 \\
1 \mathrm{~g} / 1\end{array}$ & $\begin{array}{c}9.89 \\
(18.33)\end{array}$ & $\begin{array}{c}8.83 \\
(17.28)\end{array}$ & $\begin{array}{c}18.72 \\
(25.63)\end{array}$ & $\begin{array}{c}6.35 \\
(14.59)\end{array}$ & $\begin{array}{l}15.40 \\
(23.11)\end{array}$ & $\begin{array}{c}21.75 \\
(27.80)\end{array}$ & 1436 \\
\hline 2. & $\begin{array}{l}\text { Acetamiprid } 20 \text { SP fby } \\
\text { Acetamiprid } 20 \mathrm{SP}\end{array}$ & $\begin{array}{l}0.2 \mathrm{~g} / 1 \\
0.2 \mathrm{~g} / 1\end{array}$ & $\begin{array}{c}9.87 \\
(18.31)\end{array}$ & $\begin{array}{c}9.46 \\
(17.91)\end{array}$ & $\begin{array}{c}19.32 \\
(26.08)\end{array}$ & $\begin{array}{c}5.08 \\
(13.02)\end{array}$ & $\begin{array}{c}14.20 \\
(22.14)\end{array}$ & $\begin{array}{l}19.28 \\
(26.05)\end{array}$ & 1513 \\
\hline 3. & $\begin{array}{l}\text { Chlorantraniliprole } 18.5 \text { SC fby } \\
\text { Acephate } 75 \text { SP }\end{array}$ & $\begin{array}{c}0.3 \mathrm{ml} / 1 \\
1 \mathrm{~g} / \mathrm{l}\end{array}$ & $\begin{array}{c}9.28 \\
(17.73)\end{array}$ & $\begin{array}{c}9.20 \\
(17.66)\end{array}$ & $\begin{array}{l}18.47 \\
(25.46)\end{array}$ & $\begin{array}{c}4.74 \\
(12.57)\end{array}$ & $\begin{array}{c}11.37 \\
(19.70)\end{array}$ & $\begin{array}{l}16.10 \\
(23.66)\end{array}$ & 1812 \\
\hline 4. & $\begin{array}{l}\text { Chlorantraniliprole } 18.5 \mathrm{SC} \text { fby } \\
\text { Acetamiprid } 20 \mathrm{SP}\end{array}$ & $\begin{array}{l}0.3 \mathrm{~g} / 1 \\
0.2 \mathrm{~g} / 1\end{array}$ & $\begin{array}{c}7.66 \\
(16.07)\end{array}$ & $\begin{array}{c}8.78 \\
(17.24)\end{array}$ & $\begin{array}{c}16.43 \\
(23.91)\end{array}$ & $\begin{array}{c}3.95 \\
(11.46)\end{array}$ & $\begin{array}{c}9.92 \\
(18.36)\end{array}$ & $\begin{array}{l}13.87 \\
(21.86)\end{array}$ & 1866 \\
\hline 5. & $\begin{array}{l}\text { Chlorantraniliprole } 18.5 \mathrm{SC} \text { fby } \\
\text { Indoxacarb } 15.8 \mathrm{EC}\end{array}$ & $\begin{array}{l}0.3 \mathrm{ml} / 1 \\
0.7 \mathrm{ml} / 1\end{array}$ & $\begin{array}{c}6.19 \\
(14.41)\end{array}$ & $\begin{array}{c}5.79 \\
(13.92)\end{array}$ & $\begin{array}{c}11.98 \\
(20.25)\end{array}$ & $\begin{array}{c}3.04 \\
(10.04)\end{array}$ & $\begin{array}{c}7.86 \\
(16.28)\end{array}$ & $\begin{array}{c}10.89 \\
(19.27)\end{array}$ & 2052 \\
\hline 6. & $\begin{array}{l}\text { Chlorantraniliprole } 18.5 \mathrm{SC} \text { fby } \\
\text { Flubendiamide } 39.35 \mathrm{SC}\end{array}$ & $\begin{array}{l}0.3 \mathrm{ml} / 1 \\
0.2 \mathrm{ml} / 1\end{array}$ & $\begin{array}{c}5.61 \\
(13.70)\end{array}$ & $\begin{array}{c}4.39 \\
(12.10)\end{array}$ & $\begin{array}{c}10.00 \\
(18.44)\end{array}$ & $\begin{array}{c}2.67 \\
(9.40)\end{array}$ & $\begin{array}{c}6.96 \\
(15.29)\end{array}$ & $\begin{array}{c}9.63 \\
(18.08)\end{array}$ & 2161 \\
\hline 7. & $\begin{array}{l}\text { Dimethoate } 30 \mathrm{EC} \text { fby } \\
\text { Dimethoate } 30 \mathrm{EC}\end{array}$ & $\begin{array}{l}1.3 \mathrm{ml} / 1 \\
1.3 \mathrm{ml} / 1\end{array}$ & $\begin{array}{c}11.17 \\
(19.52)\end{array}$ & $\begin{array}{c}11.34 \\
(19.68)\end{array}$ & $\begin{array}{c}22.50 \\
(28.32)\end{array}$ & $\begin{array}{c}7.93 \\
(16.35)\end{array}$ & $\begin{array}{c}14.82 \\
(22.64)\end{array}$ & $\begin{array}{c}22.78 \\
(28.51)\end{array}$ & 1490 \\
\hline 8. & Untreated control (Water spray) & -- & $\begin{array}{c}16.27 \\
(23.79)\end{array}$ & $\begin{array}{c}14.39 \\
(22.29)\end{array}$ & $\begin{array}{c}30.65 \\
(33.62)\end{array}$ & $\begin{array}{c}11.23 \\
(19.58)\end{array}$ & $\begin{array}{c}21.76 \\
(27.80)\end{array}$ & $\begin{array}{c}32.93 \\
(35.02)\end{array}$ & 1171 \\
\hline & $\mathrm{SE}+\underline{(\mathrm{m})}$ & & 1.36 & 1.02 & 1.38 & 0.91 & 1.32 & 1.13 & 137 \\
\hline & $\mathrm{CD}$ at $5 \%$ & & 4.13 & 3.04 & 4.16 & 2.73 & 4.01 & 3.43 & 414 \\
\hline & $\mathrm{CV} \%$ & & 13.46 & 10.17 & 10.51 & 11.75 & 11.15 & 9.88 & 14.08 \\
\hline
\end{tabular}

Figures of population in parenthesis are angular transformed value. 
Effects of various treatments on per cent pod and grain damage due to $\boldsymbol{H}$. armigera and M. obtuse

The results revealed that the pooled data of total pod damage due to pod borer complex in all the insecticides treatments were found significantly superior over control (Table 2). The treatment $\mathrm{T}_{6}$ chlorantraniliprole $18.5 \mathrm{SC}$ @ 0.3ml/1 fby flubendiamide 39.35 SC @ $0.2 \mathrm{ml} / \mathrm{l}$ was recorded the minimum pod damage (10.00 per cent) was found statistical significant and at par with $\mathrm{T}_{5}$ chlorantraniliprole18.5 SC @30 g a.i./ha followed by indoxacarb 15.8 EC @ $73 \mathrm{~g}$ a.i./ha (11.98 per cent).

On the basis of pooled data indicated that the total grain damage due to pod borer complex in all the insecticides treatments was found significantly superior over control (Table 2). The treatment $\mathrm{T}_{6}$ chlorantraniliprole $18.5 \mathrm{SC}$ @ $0.3 \mathrm{ml} / 1$ followed by flubendiamide 39.35 SC @ $0.2 \mathrm{ml} / 1$ was recorded the minimum grain damage (9.63 per cent) was found statistical significant and at par with $\mathrm{T}_{5}$ chlorantraniliprole $\quad 18.5 \quad$ SC $@ 0.3 \mathrm{ml} / 1$ followed by indoxacarb $15.8 \mathrm{EC} @ 0.7 \mathrm{ml} / 1$ (10.89 per cent), respectively. The present findings are in accordance with findings of Chakravarty and Agnihotri (2016) who reported that among ten different insecticidal treatments tested against pigeonpea pod borer complex ( $M$. vitrata, $H$. armigera and $M$. obtusa), alternate spray of rynaxypyr $18.5 \mathrm{SC}$ @ 30g a.i./ha and Spinosad 45 SC @ 56g a.i./ha was found to be most effective with minimum total per cent pod damage of $10.44 \%$ and maximum grain yield of 1346.67 $\mathrm{kg} / \mathrm{ha}$. However, Sambathkumar et al., (2015) also found chlorantraniliprole 18.5 SC @ $30 \mathrm{~g}$ a.i./ha and indoxacarb 15.8 EC @ $75 \mathrm{~g} \mathrm{a.i/ha}$ highly effective against $M$. obtusa in pigeonpea that resulted in significantly lower per cent pod damage (11.7\% and $13.0 \%$, respectively) as compared to $21.7 \%$ in untreated control. The present findings are also in close conformity with Patel et al., (2015) who reported that Chlorantraniliprole 18.5\% SC @ $30 \mathrm{~g}$ a.i./ha registered the lowest pod damage due to pod borer and pod fly and recorded the highest yield of pigeonpea.

\section{Effects of various treatments on grain yield of pigeonpea}

The results revealed that on the basis of pooled data indicated that the grain yields in all the insecticides treatments were found significantly superior over control (Table 2).

The treatment $\mathrm{T}_{6}$ chlorantraniliprole 18.5 SC @ 0.3ml $/ 1$ fby flubendiamide 39.35 SC @ $0.2 \mathrm{ml} / 1$ was recorded the maximum grain yield $(2161 \mathrm{~kg} / \mathrm{ha})$ was found statistical significant and at par with $\mathrm{T}_{5}$ $\begin{array}{llll}\text { chlorantraniliprole } & 18.5 & \mathrm{SC} & @ 0.3 \mathrm{ml} / 1\end{array}$ followed by indoxacarb 15.8 EC @ 0.7ml/1 (2052 kg/ha) followed by $\mathrm{T}_{4}$ chlorantraniliprole 18.5 SC @ 0.3ml $/ 1$ fby acetamiprid 20 SP@ 0.2g/l (1866 kg/ha) and $\mathrm{T}_{3}$ chlorantraniliprole18.5 $\quad \mathrm{SC} \quad @ \quad 0.3 \mathrm{ml} / 1$ followed by acephate 75 SP @ 1g/l (1812 $\mathrm{kg} / \mathrm{ha}$ ), respectively. The present findings are accordance with of Satpute and Barkhade (2012) also reported rynaxypyr 20 SC @ 40g a.i./ha as the most promising insecticide against pod borer complex of pigeonpea and to give highest yield of $17.52 \mathrm{q} / \mathrm{ha}$. The present findings are also in accordance with the earlier reports of Nishantha (2009) who reported rynaxypyr $20 \mathrm{SC} @ 30 \mathrm{~g}$ a.i./ha as superior molecule in recording lower pod damage and higher grain yield in pigeonpea against pod borer complex. Further strengthens the present findings are Wadaskar et al., (2013) also reported rynaxypyr to be highly efficacious against insect pest complex of pigeonpea was most effective in reducing the pod damage as well as pest population with maximum yield of 16.15 and $17.52 \mathrm{q}$ ha1respectively. 


\section{Acknowledgement}

The senior author is thankful to the Director of Research, Vasantrao Naik Marathwada Krishi Vidyapeeth, Parbhani for providing necessary facilities for the present investigation.

\section{References}

Ali, R.I., Awan T. H, Ahmad M. M, Saleem U, Akhtar M. 2012 Diversification of rice based cropping systems to improve soil fertility, sustainable productivity and economics. Journal of Animal and Plant Sciences. 22(1):108-112.

Anonymous. 2017 Annual Report of Research Work on pulses, Agril. Research Station, Badnapur during 2017-18.

Chakravarty, S., and Agnihotri M. 2016 Evaluation of certain novel insecticides along with biopesticides for the management of major insect pests of pigeonpea. Journal of Experimental Zoology, India. 19(2):843-850.

Durairaj, C. and T. G. Shanower, 2003 Reaction of eight short duration pigeonpea genotypes against pod borer complex in Tanil Nadu India. International chickpea and pigeonpea Newsletter, 10: 47-48.

Lal, S. S. 1996 Suppression of pod fly damage in pigeonpea to pulse beetle. Journal of Applied Biology, 4: 49-51.

Mathukia, RK, Ponkia HP, Polara AM. 2016 In situ conservation and zinc fertilization for rainfed pigeonpea (Cajanus cajan L.). The Bioscan. 11(1):247-250.

Maurya, R. P, Gupta A. K, Tiwari S, Sharma S. 2016 Cyantraniliprole, a novel insecticide for the management of lepidopteran insect pests in pigeonpea. Pesticide Research Journal. 28(2):21520.

Nishantha K M, Bhosle B. B, Patange N.R, Bhute N.K. 2009 Rynaxypyr, a new insecticide for managing pod borer complex in pigeonpea. Indian Journal of Entomology. 71(2):179-183.

Panse, V. G, Sukhatme P. V. 1985 Statistical methods for agricultural workers. ICAR publications, New Delhi, India.

Patange N. R, Chiranjeevi B. 2017 Bioefficacy of newer insecticides against pigeonpea (Cajanus cajan L. Millsp.) pod borers. Journal of Entomology and Zoology Studies. 5(3):28-31.

Patel, S. A, Patel B. C, Patel P. S, Trivedi J. B. 2015 Evaluation of newer molecules against pod borer complex of pigeonpea (Cajanus cajan (L.) Millspaugh). International Journal of Agriculture Sciences.7 (7): 587-90.

Priyadarshini, G. C., N. Reddy and D. J. Reddy 2013 Bioefficacy of selected insecticides against lepidopteran pod borers in pigeonpea. Indian Journal of Plant Protection, 41: 6-10.

Sambathkumar S, Durairaj C, Ganapathy N, Mohankumar S. 2015 Field evaluation of newer insecticide molecules and botanicals against pod borers of red gram. Legume Research. 38(2):260-7.

Satpute, N. S, Barkhade U. P 2012 Evaluation of Rynaxypyr 20 EC against pod borer complex. Journal of Food Legumes. 25(2):162-163.

Singh, A. K, Singh S. S, Prakash V, Kumar S, Dwivedi S. K. 2015 Pulses Production in India: Present Status, Bottleneck and Way Forward. Journal of Agrisearch. 2(2):75-83.

Srilaxmi, K. and R. Paul 2010 Diversity of insect pests of pigeonpea and their succession in relation to crop phenology in Gulburga, Karnataka. The Ecoscan, 4: 273-276.

Sujithra, M. and S. Chander, 2014 Seasonal incidence and damage of major insect pests of pigeonpea. International Journal of Tropical Insect Science, 28 (4) 191-200. 
Van der Maesen. 1991 LJG. Pigeonpea: Origin, History, Evolution and Taxonomy. In: Nene YL, Hall SD and Sheila UK (Eds), The Pigeonpea, $C A B$ International, Oxford shire, U.K. 15-46.

Wadaskar, R. M, Bhalkare S. K, Patil A. N. 2013 Field efficacy of newer insecticides against pod borer complex of pigeonpea. Journal of Food Legumes. 26: 62-66.

Yadav, G. S, Dahiya B. 2004 Evaluation of new insecticides/ chemicals against pod borer and pod fly on pigeonpea. Annals of Biology. 20:55-56.

\section{How to cite this article:}

Bantewad, S.D., D.K. Patil and Jahagirdar, J.E. 2018. Evaluation of Sequential Application of Insecticides against Pod Borer of Pigeonpea [Cajanus cajan (L.) Millsp.]. Int.J.Curr.Microbiol.App.Sci. 7(09): 2442-2449. doi: https://doi.org/10.20546/ijcmas.2018.709.303 